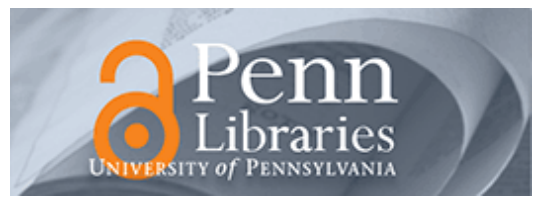

University of Pennsylvania ScholarlyCommons

Marketing Papers

Wharton Faculty Research

January 2003

\title{
The Value of Surprising Findings for Research on Marketing
}

\author{
J. Scott Armstrong \\ University of Pennsylvania, armstrong@wharton.upenn.edu
}

Follow this and additional works at: https://repository.upenn.edu/marketing_papers

\section{Recommended Citation}

Armstrong, J. S. (2003). The Value of Surprising Findings for Research on Marketing. Retrieved from https://repository.upenn.edu/marketing_papers/84

Postprint version. Published in Journal of Business Research, Volume 56, Issue 1, January 2003, pages 91-92.

Publisher URL: http://dx.doi.org/10.1016/S0148-2963(02)00389-2

This paper is posted at ScholarlyCommons. https://repository.upenn.edu/marketing_papers/84

For more information, please contact repository@pobox.upenn.edu. 


\title{
The Value of Surprising Findings for Research on Marketing
}

\author{
Abstract \\ In the work of Armstrong (Journal of Business Research, 2002), I examined empirical research on the \\ scientific process and related these to marketing science. The findings of some studies were surprising. \\ In this reply, I address surprising findings and other issues raised by commentators.

\section{Comments} \\ Postprint version. Published in Journal of Business Research, Volume 56, Issue 1, January 2003, pages \\ 91-92. \\ Publisher URL: http://dx.doi.org/10.1016/S0148-2963(02)00389-2
}


Reprinted with permission from Journal of Business Research (2003), 91-92.

(C) 2003 Elsevier Science Inc.

\title{
The Value of Surprising Findings for Research on Marketing
}

\author{
J. Scott Armstrong, University of Pennsylvania
}

\begin{abstract}
In the work of Armstrong (Journal of Business Research, 2002), I examined empirical research on the scientific process and related these to marketing science. The findings of some studies were surprising. In this reply, I address surprising findings and other issues raised by commentators.
\end{abstract}

\section{Findings are Sometimes Surprising to Academics}

Rossiter (2002) disagrees with a number of my conclusions. These were generally based on surprising findings. He does not offer contradictory evidence to my conclusions. Here are three exaples.

(1) Rossiter claims that the probability of acceptance is higher for good papers than for bad papers. My earlier review of the literature led me to the Authors' Formula as a way to increase the probability of acceptance. Among other things, the guidelines in the Authors' Formula suggest that authors have a higher probability of being published if they submit complex and unreadable papers that have no obvious importance.

(2) Rossiter offers empirical evidence to refute the null hypothesis that there is no relationship between statistical significance and replicability. But this null hypothesis is unreasonable. My conclusion was that statistical significance does not correspond well to replicability and is often misinterpreted; Rossiter's evidence is not relevant to these conclusions.

(3) Rossiter claims that acceptance in leading journals is a good discriminator of studies; thus, the current system is sufficient. My proposal is that journals should continue to discriminate, but they should provide more information than they do now. Thus, they could rate the quality of the paper on a five-point scale and make the reviews available (in print for important reviews and on the Internet for others). Journal editors should also encourage continuing peer review on the Internet. Editors need not act as censors given the economics of publishing on the Internet.

\section{Other Issues}

After criticizing me for wanting to publish everything, Rossiter claims that I want to restrict publications to papers that are only relevant to principles. While I think all papers should 
be published, I would put more emphasis on those that contribute to principles that can improve research and practice in marketing.

I do not share Rossiter's concern over plagiarism due to Internet publication. First, plagiarism among academics seems to be rare in management science (Armstrong 1983). True, cheating among students is regarded as normal behavior at many universities, but I do not see how we can design the scientific publication system to deal with such behavior. Second, I expect Internet publication to allow authors to stake their claims earlier and to be able to trace their use by others.

I should clarify one issue with respect to Lehmann's (202) commentary. While asking authors to suggest reviewers, I would not restrict the reviewers to these suggestions. A large and diverse group of reviewers can improve papers.

While I like the emphasis that Lehmann gives to accepting papers based on research proposals, I do not think the dissertation analogy is a good one. In my opinion, Ph.D. dissertations have a low likelihood of making important findings. Thus, journals should allow their associate editors to seek papers on various topics and to accept proposals for eventual publication. If one were concerned to have more control over the process, journals could say that proposals must be sponsored by at least two associate editors.

\section{Hope for the Future}

Because findings from empirical research on the discovery and communication of important findings yielded advice that is surprising, editorial boards are likely to resist the resultant changes in editorial procedures. This is based on my experience and that of other editors. For example, I wrote the editorial procedures for the Journal of Forecasting and for the International Journal of Forecasting when those journals were launched. When I later discovered evidence that some of my original procedures could be improved upon, I proposed changes. These changes met with resistance from the editorial boards.

Rather than rejecting findings because our experience informs us that they are wrong, journals might benefit by conducting fields tests of alternative policies. Indeed, some journals have experimented with new procedures, and new journals seem to be especially open to new approaches. The availability of the Internet may lead journals to further experimentation as a matter of long-term survival because the economics of publishing is being altered.

Some of the detailed recommendations in my paper become less important if a journal were to adopt the recommendation to publish all papers. My prediction is that this would reduce the number of papers published because it would remove the incentive for quantity. The number of papers with important findings would likely increase because researchers could become bolder in their selection of topics and because important findings would not be rejected. 
The publications of open peer review would increase the information that we have about the quality of the papers published. It would also discourage authors from publishing papers that were judged to be of poor quality.

\section{References}

Armstrong, J. S. (1983), “Cheating in management science,” Interfaces, 13 (August), 2-29 (in full text at jscottarmstrong.com)

Armstrong, J. S. (2002), “Discovery and communication of important marketing findings: Evidence and proposals,” Journal of Business Research.

Lehmann, D. R., (2002), “Finding important findings,” Journal of Business Research.

Rossiter, J. R. (2002), “Qualifying the importance of findings,” Journal of Business Research. 